\title{
Efektifitas Media Pembelajaran IPA Berbasis Masalah Untuk Meningkatkan Kreativitas Mahasiswa Calon Guru SD
}

\author{
Suriya Ningsyih ${ }^{1)}$, Syahriani Yulianci ${ }^{1{ }^{*}}$, Adi Apriadi Adiansha ${ }^{1)}$, Nurjumiati $^{1)}$, Asriyadin $^{1)}$ \\ ${ }^{1)}$ STKIP Taman Siswa Bima \\ *yulianci.syah@gmail.com
}

\begin{abstract}
Abstrak: Penelitian ini fokus untuk menguji efektifitas dari media pembelajaran IPA berbasis masalah dalam meningkatkan kreativitas mahasiswa calon guru SD yang bertujuan untuk melatih mahasiswa calon guru meningkatkan kreativitas dalam mengajar pembelajaran IPA. Desain penelitian ini menggunakan One Shot Case Study yang dilaksanakan pada mahasiswa calon guru SD STKIP Taman Siswa Bima yang menempuh matakuliah pembelajaran IPA SD kelas lanjut. Hasil karya mahasiswa diobservasi sebagai hasil berpikir kreatif mahasiswa dalam mendesain media pembelajaran IPA berbasis masalah. Instrumen yang digunakan dalam penelitian ini berupa lembar observasi menggunakan skala Penyekoran Holistik. Hasil Analisis data diperoleh nilai rata-rata persentase sebesar $84 \%$ dengan kategori sangat kreatif. Berdasarkan hasil analisis data, dapat disimpulkan bahwa media pembelajaran IPA berbasis masalah efektif dalam meningkatkan kreativitas mahasiswa calon guru SD.
\end{abstract}

Kata Kunci: Media Pembelajaran IPA, Berbasis Masalah, Kreativitas Mahasiswa

\section{Pendahuluan}

Pembelajaran IPA merupakan pelajaran yang mempelajari tentang gejala alam melalui proses dan produk ilmunya. Tujuan pembelajaran IPA berperan penting dalam upaya peningkatan kualitas pendidikan yang berkaitan dengan kehidupan sehari-hari yang disesuaikan dengan konsep-konsep sains sehingga peserta didik dapat mengembangkan rasa ingin tahu dan sikap positif terhadap sains. Dalam menyelenggarakan pembelajaran aktif, kreatif, efektif dan menyenangkan, guru perlu mendesain perencanaan pembelajaran, seperti pemilihan model pembelajaran yang mengasah kemampuan berpikir tingkat tinggi, media yang menarik peserta didik serta alat evaluasi yang sesuai dengan tujuan pembelajaran. Oleh karena itu guru dituntut untuk dapat meningkatkan kreativitasnya dalam mengembangkan media pembelajaran IPA (Ningsyih, 2018).

Dalam menghasilkan suatu karya, mahasiswa calon guru SD selain meningkatkan aspek kognitif peserta didik, juga dituntut untuk mengembangkan kreativitas terhadap produk yang didesain dan aktivitas mahasiswa calon guru SD dalam pengalaman beajar serta interaksi di kelas. Di era pendidikan 4.0 saat ini, mahasiswa calon guru SD dituntut untuk mengembangkan kreativitas yang tinggi dalam proses belajar mengajar, sehingga kedepannya akan menghasilkan pendidik yang profesional dalam bidangnya (Hairunnisa, 2019). Namun bila dilihat berdasarkan fakta yang ada saat ini tidak semua pendidik mampu mengembangkan kreatifitasnya dalam proses mengajar. Akibatnya mahasiswa calon guru tidak mampu untuk menyesuaikan diri terhadap tuntutan dalam dunia nyata. Hal ini melahirkan Sumber Daya Manusia (SDM) yang tidak mampu bersaing dalam dunia global.

Oleh karena itu diperlukan adanya modifikasi atau variasi dalam proses pembelajaran, maka perlu diupayakan strategi yang memberikan suasana pembelajaran IPA yang mampu meningkatkan aktivitas dan kreativitas mahasiswa calon guru. Model pembelajaran berbasis masalah efektif dalam meningkatkan kreativitas mahasiswa. Model pembelajaran berbasis masalah merupakan pembelajaran yang dapat memecahkan suatu permasalahan dari fenomena yang ada dalam kehidupan sehari-hari yang dihubungkan dan dijelaskan dengan konsep sains sehingga dapat meningkatkan keterampilan dan kreativitas peserta didik. Model pembelajaran berbasis masalah mendorong peserta didik berusaha sendiri mencari pemecahan masalah serta pengetahuan yang menyertainya mampu menghasilkan pengetahuan yang benar-benar bermakna (Sumarta, 2017). Pembelajaran 
berbasis masalah idealnya menerapkan pendekatan berpusat pada instruksional dan kurikuler yang memberi peluang kepada peserta didik untuk melakukan penelitian, mengintegrasikan teori, praktik, menerapkan pengetahuan dan mengembangkan keterampilannya (Savery, 2015).

\section{Metode}

Tehnik analisis data menggunakan desain One Shot Case Study. Penelitian ini dilaksanakan pada mahasiswa calon guru SD STKIP Taman Siswa Bima yang menempuh mata kuliah pembelajaran IPA SD kelas lanjut. Pada penelitian ini mahasiswa membuat media pembelajaran IPA berbasis masalah. Hasil karya mahasiswa diobservasi sebagai hasil berpikir kreatif mahasiswa dalam mendesain media pembelajaran IPA berbasis masalah. Instrumen yang digunakan dalam penelitian ini berupa lembar observasi menggunakan skala Penyekoran Holistik. Data yang diperoleh dianalisis dengan menggunakan rumus sebagai berikut:

$$
\begin{gathered}
N P=\frac{R}{S M} \times 100 \% \\
\text { (Purwanto, 2010) }
\end{gathered}
$$

Keterangan:

$\mathrm{NP}=$ Nilai presentase kemampuan berpikir kreatif

$\mathrm{R} \quad=$ Skor mentah yang di peroleh mahasiswa

$\mathrm{SM}=$ Skor maksimum observasi kognitif / afektif yang bersangkutan

Kategori penilaian kreativitas mahasiswa calon guru SD dalam membuat media pembelajaran IPA SD terlihat dalam Tabel 1.

Tabel 1. Kategori Kreativitas Mahasiswa

\begin{tabular}{ccc}
\hline No & Persentase yang Diperoleh & Kategori \\
\hline 1 & $81 \%-100 \%$ & Sangat Kreatif \\
2 & $61 \%-80 \%$ & Kreatif \\
3 & $41 \%-60 \%$ & Cukup Kreatif \\
4 & $21 \%-40 \%$ & Kurang Kreatif \\
5 & $0 \%-20 \%$ & Tidak Kreatif \\
\hline & & (Arni, 2017)
\end{tabular}

\section{Hasil dan Pembahasan}

Penelitian ini bertujuan untuk meningkatkan kemampuan dan keterampilan kreativitas mahasiswa calon guru SD dalam membuat produk media pembelajaran SD berbasis masalah yang berkaitan dengan kehidupan sehari-hari. Kualitas aspek yang diukur pada penelitian ini ada 4 aspek. Aspek pertama yaitu aspek perencanaan, pada tahap ini mahasiswa calon guru SD mulai mengkaji literatur, mencari materi yang dihubungan dengan kehidupan sehari-hari, Aspek kedua yaitu aspek pelaksanaan (membuat produk), pada aspek ini mahasiswa mulai mendesain media pembelajaran IPA berbasis masalah yang dihubungkan dengan kehidupan sehari-hari untuk meningkatkan kemampuan berpikir tingkat tinggi peserta didik SD. Aspek ketiga, presentasi, pada tahap ini mahasiswa calon guru SD melakukan presentasi produk media pembelajaran IPA SD, aspek keempat laporan, dimana pada tahap ini mahasiswa menyusun laporan akhir dari produk yang di buat. Data hasil kreativitas mahasiswa diobsevasi menggunakan angket dengan memberikan tanda ceklis pada kolom nol, satu dan dua pada tiap-tiap aspek yang diamati. Hasil rata-rata persentase kreativitas mahasiswa calon guru SD dalam membuat media pembelajaran IPA SD dapat dilihat pada Tabel 2.

Berdasar tabel table 2, hasil analisis rata-rata persentase kreativitas mahasiswa calon guru SD yang diukur masing-masing aspeknya yaitu, pada aspek perencanaan (mendesain) diperoleh nilai sebesar 58\% dengan kategori cukup kreatif. Pada aspek pelaksanaan ( membuat model pembelajaran) diperoleh nilai sebesar 77\% dengan kategori kreatif. Sedangkan pada aspek presentasi rata-rata persentase sebesar $84 \%$ dengan kategori sangat kreatif. Sementara pada aspek laporan akhir diperoleh nilai sebesar 53\% dengan kategori cukup kreatif. Sehingga dapat diketahui nilai rata-rata persentase kreativitas mahasiswa calon guru SD dalam membuat media pembelajaran 
IPA SD berbasis masalah yaitu berada pada kategori kreatif dengan niali rata-rata persentase sebesar $68 \%$, ini dapat dilihat dari antusias mahasiswa yang cukup kreatif dalam membuat media pembelajaran IPA SD yang dihubungkan dengan kehidupan sehari-hari. Hal ini sejalan dengan hasil penelitian (Fahrudin, 2017) yang mengatakan bahwa pembelajaran berbasis masalah efektif untuk meningkatkan kreativitas mahasiswa, hal ini terlihat dari proses pembelajaran berbasis masalah dapat memfasilitasikan pembelajaran yang aktif dan kreatif untuk melatih kemampuannya secara komprehensif dan meningkatkan kinerja mahasiswa. Pembelajaran berbasis masalah sebagai alat yang paling berguna dalam hal belajar mandiri, interaksi, orientasi, dan presentasi mahasiswa calon guru.

Tabel 2. Hasil Uji Kreativitas Mahasiswa Calon Guru SD

\begin{tabular}{clcc}
\hline No & \multicolumn{1}{c}{ Aspek yang dinilai } & Nilai Persentase & Kategori \\
\hline 1 & Perencanaan (mendesain) & $58 \%$ & Cukup Kreatif \\
2 & Pelaksanaan (membuat model pembelajaran) & $77 \%$ & Kreatif \\
3 & Presentasi & $84 \%$ & Sangat Kreatif \\
4 & Laporan Akhir & $53 \%$ & Cukup Kreatif \\
\hline & Rata-rata persentase kreativitas mahasiswa & $68 \%$ & Kreatif \\
\hline
\end{tabular}

Dilihat dari keempat aspek yang diukur tersebut, aspek yang paling tinggi rata-rata persentasenya yaitu pada aspek presentasi sebesar $84 \%$ dengan kategori sangat kreatif, hal ini menunjukan bahwa proses diskusi, tanya jawab mahasiswa sangat aktif ketika proses belajar mengajar berlangsung. Problem-based learning (PBL) memberikan peran aktif mahasiswa dalam proses belajar mengajar sehingga mereka mempunyai keahlian dalam berkomunikasi dan menyampaikan pendapat. Melalui presentasi mahasiswa dapat meningkatkan pemahaman secara aktif serta terampil memberikan alasan tingkat tinggi. Mahasiswa juga mempunyai kemampuan untuk menggabungkan aspek sosial dan etika kedalam ilmu sains, berkolaborasi dalam belajar, mempunyai sifat kepemimpinan, terampil dalam berkomunikasi dan berempati serta dapat mengidentifikasi kekuatan dan kelemahan yang dimilikinya (Susanti et al, 2017).

Menurut Awang (2008) berdasarkan dari data hasil penelitiannya mengatakan bahwa pembelajaran berbasis masalah terbukti dapat mendorong peningkatan kemampuan berpikir kreatif mahasiswa, hal ini dilihat dari hasil belajar mahasiswa yang memiliki nilai kreativitas yang tinggi. Oleh karena itu pembelajaran berbasis masalah memiliki peluang dalam mengembangkan kreativitas mahasiswa sehingga efektif untuk mengembangkan media pembelajaran (Astuti, 2016).

\section{Kesimpulan}

Berdasarkan hasil analisis data dan pembahasan, maka dalam penelitian ini dapat disimpulkan bahwa media pembelajaran IPA SD berbasis masalah efektif untuk meningkatkan kreativitas mahasiswa calon guru SD. Saran untuk peneliti selanjutnya, dapat menggunakan model pembelajaran atau pun dengan variasi-variasi lain yang berbeda untuk melatih meningkatkan kreativitas mahasiswa calon guru SD.

\section{Daftar Pustaka}

Arni, W., Asmila, A. 2017. Analisis Kemampuan Berpikir Kreatif Pada Materi Cahaya Siswa Kelas Viii Smp Xaverius Kota Lubuklinggau. SPEJ (Science and Physics Education Journal), 1 (1): 23 - 38.

Astuti, R.K. 2016. Model Pembelajaran Berbasis Masalah Untuk Meningkatkan Kreativitas Siswa Dalam Membuat Proyek Sains. PSEJ, 1 (1) : 50-59.

Awang, H., \& Ramly, I. 2008. Creative Thinking Skill Approach Through Problem-Based Learning: Pedagogy and Practice in the Engineering Classroom. International Journal of Human and Social Sciences, 3(1) : 18-23.

Fahrudin Fardik, A. 2017. Efektivitas Problem Based Learning Terhadap Kemampuan Berpikir Kreatif Mahasiswa Program Studi Tadris Matematika. Jurnal Teori dan Aplikasi Matematika, 1 (1) : 41-48. 
Hairunisa., Hakim, A.R., Nurjumiati.2019. Studi Pengaruh Model Pembelajaran Berbasis Proyek (Project Based Learning) Terhadap Kreativitas Mahasiswa Program Studi PGSD Pada Mata Kuliah Konsep Dasar IPA. Jurnal Pendidikan MIPA, 9 (2) : 93-96.

Ningsyih, S., Andayani, Y., Hakim, A. 2018. The Effectiveness of Problem Based Worksheet to Improve Senior High School Students' Critical Thinking Skills. Unnes Science Education Journal, 7 (3) : 266-271.

Purwanto, Ngalim. 2010. Prinsipprinsip dan Teknik Evaluasi Pengajaran. Bandung: Remaja Rosdakarya.

Sumarta I Gusti, B. 2017. Pengaruh Pembelajaran Berbasis Masalah Berbantuan Mind Map Terhadap Keterampilan Berpikir Kreatif Dan Hasil Belajar Biologi Pada Siswa SMK. Jurnal Ilmiah Pendidikan dan Pembelajaran, 1 (1) : 68-77.

Susanti, P., Lisiswanti, R., Soleha, T., Saputra, O., Okyfany. 2017. Hubungan Kualitas Skenario Terhadap Keefektifan Diskusi ProblemBased Learning (PBL) Blok Emergency Pada Mahasiswa Fakultas Kedokteran Universitas Lampung. Medulla,7(4) : 157-163.

Savery, J. R. 2015. Overview of problem based learning Definitions and distinctions. Interdisciplinary Jornal of Problrm-Besed Learning, 1(1). 